\title{
Hnutí Camphill na pozadí sociálněpedagogické reformy počátku minulého stoleti ${ }^{1}$
}

\author{
ŠÁRKA KLÍMOVÁ
}

\begin{abstract}
Abstrakt: Historicko-pedagogická studie pojednává o mezinárodnim hnuti Camphill, divvodech jeho vzniku ve čtyřicátých letech 20. století, o úloze rakouského lékaře Karla Königa v roli nejen duchovniho vĩdce hnuti, stejnè jako o motivaci zakladatelì hnuti k založeni prvniho společenstvi. Studie si klade za cil seznámit čtenáré s myšlenkovými východisky hnuti Camphill v kontextu doby jeho vzniku a v kontextu základniho ideového rámce, z něhož hnutí čerpalo - anthroposofie. Popisuje rovněž úlohu léčebné pedagogiky a sociálni trojčlennosti jako základnich pilíru camphillu.
\end{abstract}

Kličová slova: hnuti Camphill, anthroposofie, Karl König, Rudolf Steiner, léčebná pedagogika, idea sociálni trojčlennosti.

\section{ÚvODEM}

„Zdravý sociální život nastává, když $v$ zrcadle každé lidské bytosti nacházi svioj odraz celé společenství a když ve společenstvi žije sila každé jednotlivé duše."

Průpověd', která tvoří úvodní rádky, bývá $\mathrm{v}$ různých jazykových obměnách mottem všech camphillů na celém světě. Autorem je tvůrce myšlenkového směru zvaného anthroposofie, ${ }^{3}$ Rudolf Steiner. ${ }^{4}$
Rakouský myslitel, lékař, pedagog a mystik nabídl reformně nakloněné středoevropské společnosti počátku 20. století mnoho podnětů, vycházejících právě z anthroposofie. Mezi nimi i tzv. základní sociální zákon, ${ }^{5}$ který měl nahradit dosavadní nefungující společenský řád, jehož nedostatečnost byla prokázána první světovou válkou. Základní sociální zákon se (stejně jako náplň zmíněné průpovědi) stal součástí nejen filozofické koncepce celo-

\footnotetext{
${ }^{1}$ Článek vznikl v rámci projektu IGA SPP 43416031/31.

${ }^{2}$ Reordering of Society: The fundamental social law [online]. (2017). Dostupné z http://wn.rsarchive.org/ Articles/FuSoLa_index.html

${ }^{3}$ Anthroposofie je eklektický myšlenkový proud, který Rudolf Steiner vytvořil na začátku 20. století, inspirován např́íklad theosofíi Marie Blavatské či rosekruciánstvím.

${ }^{4}$ Rudolf Steiner (1861-1925) byl rakouský myslitel, tvůrce myšlenkového proudu antroposofie, jejímiž praktickými aplikacemi jsou např́klad waldorfská pedagogika, Obec křestanů, biodynamické zemědělství, eurytmie aj. ${ }^{5}$ Základní sociální zákon říká, že „blaho určitého celku spolupracujících lidí je tím větší, čím méně jednotlivec požaduje výnosy svých výkonů sám pro sebe, to znamená, čím víc z těchto výnosů dává svým spolupracovníkům a jeho vlastní potřeby jsou uspokojovány ne z vlastních výkonů, ale z výkonů ostatních“ (Steiner, 2006).
} 
světově rozšířeného hnutí alternativních komunit, pro něž se podle místa vzniku vžil název camphill, ale i nedílnou součástí praktického života v nich.

Tvůrcem filozofického rámce camphillu $^{6}$ a zároveň jedním ze zakladatelů hnutí Camphill, byl duchovní žák Steinera a stejně jako Steiner žádaný praktický lékař, Karl König. V komunitě, kterou se svými spolupracovníky vytvořil, nechal $\mathrm{k}$ lidem promlouvat hned několik ze Steinerových anthroposofických podnětů. Léčebnou pedagogiku a sociální terapii jako významné prvky terapeutického přístupu, který je alternativou $\mathrm{k}$ běžným postupům péče, výchovy a vzdělávání dětí a dospělých $s$ mentálním postižením. Rovněž již zmíněný základni sociálni zákon, pohybové umění nazvané eurytmie a často také biodynamické zemědělství. Ve školách, které jsou součástí camphillů, jejichž cílovou skupinou jsou děti, našlo uplatnění kurikulum waldorfských škol.

Předložený článek se zabývá představením hnutí Camphill - impulsy vedoucími $\mathrm{k}$ jeho vzniku ve čtyrícátých letech 20 . století, úloze Karla Königa a jeho spolupracovníků při jeho založení, myšlenkovými východisky hnutí Camphill, a to na pozadí celkového kontextu sociálněpedagogické reformy společnosti první poloviny 20. století a ideového rámce antroposofie. Rovněž se zabývá nastíněním teorie a praxe léčebné pedagogiky a idey sociální trojčlennosti jako hlavních pilîrů terapeutické práce v camphillu.

\section{SoCIÁlNĚ PEDAGOGICKÁ REFORMA 1. POLOVINY 20. STOLETÍ A JEJÍ VLIV NA ZAKLADATELE HNUTí CAMPHILL}

20. století bývá právem považováno za století dítěte, století dětství. Není však definované pouze rozvojem práv dětí a domněnkou, že je třeba radikálně změnit přístup $\mathrm{k}$ jejich výchově i způsob systémového školního vzdělávání. S prudkým rozvojem evropské společnosti, podníceným průmyslovou revolucí, se výrazně zlepšilo také postavení dělnické třídy, zesílilo ženské hnutí, hnutí za uchování míru a rozvíjela se i spolková činnost, at už politického, zájmového nebo sportovního zaměřní.

Nový pohled na svět se zákonitě projevil i v myšlení společnosti, $v$ němž je patrný přechod od spekulativních myšlenek $a$ vědeckých představ bez důkazů $\mathrm{k}$ empirismu, a to nejen $\mathrm{v}$ prírodních vědách, ale rovněž ve vědách společenských (srov. např. Fajkus, 2005).

Během 19. století Evropa prosperovala jako nikdy předtím. Počet jejích obyvatel se zdvojnásobil - tvořila $25 \%$ světové populace a produkovala více než $60 \%$ průmyslových výrobků celého světa. Industriální společnost dospěla do stadia poměrného blahobytu, nové objevy a výrobky přinášely ideu dokonalosti člověka, který má schopnosti ovládnout vše kolem sebe. Životní standard, který vzrostl na konci

\footnotetext{
$\overline{{ }^{6} \text { Název camphill, který se později pro komunitu i celé hnutí vžil, vznikl podle jména prvního komunitního }}$ domu - Camphill House. Dnes je obecným označením všech komunit tohoto typu a z toho důvodu je uváděn $s$ malým počátečním písmenem - camphill. Oproti tomu při označení celého hnutí je používán (stejně jako v zahraničí) název Camphill s velkým písmenem.
} 
19. století, pomáhal začlenit do společnosti dělníky. Pracující třída se změnila v nižší střední třídu, práva dělníků $\mathrm{v}$ porovnání s 19. stoletím vzrostla např́íc Evropou (Smith in Stearns, 2001, s. 205-213).

Jak už bylo zmíněno, společenské skupiny se začaly emancipovat - usilování žen o získání práva volit, které trvalo již od poloviny 19. století, dosáhlo ve dvacátých letech 20. století vrcholu a ženy získaly volební právo $\mathrm{v}$ mnoha zemích. Emancipovat se začaly rovněž $\mathrm{v}$ oblasti pracovních př́ležitostí a kariérního růstu. Zářným př́kladem může být významná aktérka pedagogického reformního hnutí Maria Montessori (1870-1952), která se stala historicky první italskou lékařkou a jejiž životní př́iběh je ukázkou boje žen za právo na vzdělání a práci v oboru, který byl do té doby považován za ryze mužský. Ženy se rovněž začaly ve vyspělých evropských státech angažovat $\mathrm{v}$ politice. Jak uvádí Smith (Stearns, 2001, s. 214), napríklad ve Velké Británii bylo v sedmdesátých letech 19. století v lokální politice aktivních 7 tisíc žen. $\mathrm{O}$ čtyřicet let později dosáhl tento počet 76 tisíc.

$\mathrm{V}$ duchu globálních změn $\mathrm{v}$ uvažování člověka, jeho hledání a porovnávání důkazů o tom, že něco je lepší než to předchozí a proč, přišel i zmíněný obrat ke zkoumání dítěte. Podle nového přesvědčení je dětství hodnotná část života každého člověka a je třeba $\mathrm{k}$ ní změnit príistup, a to nejen v opatřeních týkajících se pracovní doby dětí a náplně práce, ale rovněž ve způsobu jejich vzdělávání.
Současně $s$ tendencemi zaměřujícími se na dětství tzv. zdravých dětí se objevil prostor také pro změnu postoje společnosti $\mathrm{k}$ dětem postiženým nějakým handicapem. Napříc Evropou se začaly realizovat vědecké výzkumy, byly zakládány nové ústavy, jejichž záměrem už nebyla pouhá izolace postižených dětí, ale také snaha těmto dětem pomoci. Byla to opět Montessori, kdo se ( $v$ návaznosti zejména na práci lékařù Itarda a Séguina) těmto dětem věnoval. Od roku 1921 začaly vznikat rovněž léčebně-pedagogické domovy, ${ }^{7}$ které oproti běžným ústavům poskytovaly rodinnější prostředí a komunitní charakter.

Rovněž začátek 20. století si vybrala pro vydání své knihy Století ditěte švédská pedagožka Ellen Keyová (1849-1926). Tato přední zástupkyně reformní severské pedagogiky přelomu 19. a 20. století shrnula ve své knize názory na výchovu a vzdělávání, které někteří pedagogové i učitelé vyslovovali již delší dobu. Její kniha nastartovala tzv. reformní pedagogické hnutí, které vzešlo z kritiky tradiční školy, podléhající herbartismu, a výchovy (více např. Václavík, 1997).

Druhou významnou ženou reformního pedagogického hnutí byla již v několika souvislostech zmíněná Maria Montessori. Montessori se věnovala péči a vzdělávání mentálně postižených dětí a metody, které vyvinula při práci $s$ nimi, následně aplikovala i na práci s dětmi tzv. normálními. Již v roce 1907 otevřela v Římě dům určený pro chudé děti předškolního

${ }_{7}^{7}$ Jednou z léčebně-pedagogických institucí, které vznikly na přelomu dvacátých a třicátých let 20. století, byl domov v Pilgramshainu, kde byl König lékařem a kam se na sedm let přestěhoval s celou rodinou. 
věku (více např. Rýdl, 1994; Matulčíková, 2007). Motessori začala s dětmi s mentálním postižením pracovat 14 let před tím, než Wegmanová se Steinerem vytvořili koncepci léčebné pedagogiky a začali ji uplatňovat $\mathrm{v}$ praxi léčebně-terapeutických domovů vznikajících po celé Evropě.

Americkým stěžejním pedagogickým reformátorem prélomu století byl bezpochyby John Dewey (1859-1952), jehož největším př́nosem byla koncepce pragmatismu. Ve Francii patřil mezi významné osobnosti pedagogické reformy tohoto období Celestine Freinet, v Německu Peter Petersen a v Belgii Ovide Decroly (více Rýdl, 1994; Matulč́ková, 2007).

Výše jmenovaní jsou však jen zástupci dlouhé řady pedagogů, kteří se zasloužili o vznik a rozšíření tzv. hnutí nových škol, které našlo své zástupce i u nás. $V$ českém prostředí stojí za zmínku např́íklad J. Mrazík, F. Bakule, J. Úlehla, L. Havránek, E. Štorch (Reformní hnutí, 1996).

Žádný z představitelů reformního pedagogického hnutí neovlivnil životní i profesní dráhu zakladatelů hnutí Camphill tolik jako Rudolf Steiner (1861-1925). Přední zástupce reformní pedagogiky v Rakousku vystudoval lékařskou fakultu, ale od mládí se věnoval rovněž spiritismu. Byl členem Theosofické společnosti, založené Helenou P. Blavatskou, a na začátku 20. století vytvořil anthroposofii jako eklektický filozofický směr spojující poznatky z theosofie, ale také z rosekruciánství a dalších filozofických směrů a koncepcí.

Anthroposofie je moderní duchovní cestou, která respektuje svobodu každého jednotlivce. Vychází z trojčlenného pojetí člověka, které stojí na tvrzení, že každý člověk je tvořen nejen fyzickým tělem, ale i duševním a duchovním. Nad třemi těly se v každé lidské bytosti skrývá ještě Já, které se po smrti i se svými zkušenostmi, které nabylo, znovu reinkarnuje (Steiner, 2000). Pojetí člověka, které vychází z antroposofie, říká, že jsou si všechny lidské bytosti rovny bez rozdílu - nehledě na jejich pohlaví, věk, zdravotní stav, národnost nebo třeba náboženské vyznání.

Právě toto pojetí člověka bylo bezesporu tím, čím Königovi a ostatním zakladatelům camphillu byla anthroposofie velmi sympatická. Věrili, že díky anthroposofii dokážou vytvořit bratrství, v němž si všichni (bez rozdílu) budou rovni a kde i víra bude mít ryze individuální charakter. To se jim v roce 1940 podařilo a anthroposofické pojetí člověka zůstalo dodnes jedním $\mathrm{z}$ výrazných specifik camphillů.

\section{KARL KÖNIG - REFORMA SPOLEČNOSTI NA POZADÍ JEDNOHO ŽIVOTNÍHO PŘíBĚHU}

Druhá polovina 19. století a začátek 20. století byly ve Vídni poznamenány bouřlivým rozvojem. Podstatná část města byla nově přestavěna a před první světovou válkou se Vídeň pyšnila statusem čtvrtého největšího města. Počet obyvatel přesáhl dva miliony a rakouské hlavní město bylo významným centrem uměleckého života.

Do umělecké a pokrokové Vídně se na konci záŕí roku 1902 narodil Karl Kö- 
nig. $S$ vrozenou vadou chodidel, která poznamenávala jeho chůzi po celý život, byl jediným dítětem svých židovských rodičů. Od dětství trpěl migrénami a depresemi, což mohlo vyplývat rovněž ze skutečnosti, že první světová válka se všemi hrůzami, které přinesla, vstoupila do Königova rodného města $v$ jeho dvanácti letech a König se tak v citlivém věku dospívání stal svědkem každodenních lidských tragédii. Okolní bída a nedostatek jídla v ulicích udělaly na Königa nepochybně hluboký dojem, přestože jeho vlastní rodina nikdy nestrádala (Müller-Wiedemann, 1996, s. 12-27)

Jak uvádějí např́íklad Müller-Wiedemann (1996) a Jackson (2014), König již v období povinné školní docházky projevoval intelektové schopnosti předcházející jeho vrstevníky. I to mohlo být prýčcinou skutečnosti, že měl v dětství velmi málo přátel. Jak podotýká ve své autobiografii Königova matka (Koenig, 2010), rodiče si byli vědomi osamělosti svého syna, avšak nevěděli si rady s tím, jak ji vyléčit. Kvůli provozování obchodu s obuví jim rovněž na péči o jediného syna nezbývalo mnoho času.

Ani život $\mathrm{v}$ Leopoldstadtu, židovské čtvrti, nebyl pro Königa v narůstajícím antisemitismu Vídně dvacátých let zřejmě jednoduchý (Jackson, 2014, s. 2). V osmnácti letech pak König definitivně opustil židovskou komunitu, $\mathrm{k}$ čemuž se neformálně rozhodl již v dospívání, a stal se křestanem (Müller-Wiedemann, 1996). Pokřtěn (jak dnes již víme z jeho deníko- vých zápisů) byl ale českým knězem Obce křestanů Josefem Králem až v roce 1937. ${ }^{8}$

$\mathrm{V}$ době, kdy opouštěl židovskou komunitu, se König na výstavě moderního umění poprvé setkal se jménem Steinera a o tři roky později se rozhodl následovat cestu anthroposofie, která korespondovala $s$ jeho vlastním vnímáním světa. $V$ té době již studoval vídeňskou lékařskou fakultu, kde se později specializoval na embryologii (tamtéž, s. 45)

Důležitým mezníkem Königova života byl 7. listopad 1927, kdy stejně jako jeho pozdějš́i žena, Tilla Maasberg, přijel do Institutu léčebné pedagogiky Dr. Wegmanové v Arlesheimu, aby tam nastoupil jako lékař, a Tilla jako účastnice léčebně terapeutického kurzu Wegmanové. König byl Wegmanovou požádán, aby část své pracovní doby trávil jako ošetřující lékař v Sonnenhofu - léčebně terapeutickém domově, který založila jako součást Institutu. Setkání s postiženými dětmi definitivně předurčilo Königův další život. Na festivalu zvaném Advent Garden pozoroval König postižené děti nesoucí svíčku doprostřed spirály z chvojí, kde ji zapálily o větší svíčku a následně ji položily do chvojí obvodu spirály. Při té príležitosti dospěl ke zjištění, že jeho životním úkolem je vytvořit takto potřebným dětem domov. To, co od této chvíle König hledal a o co usiloval, označil spojením Candle on the Hill - místo, které bude jako svíčka na vrcholu svítit na cestu všem postiženým dětem (Müller-Wiedemann, 1996; Bock, 2004).

${ }^{8}$ Karl König Archive, Aberdeen, Diář Karl Königa, 1937. R10D1_0057 
3. SEMÍNKo STŘEdOEVROPSKÉ

REFORMNÍ MYŠLENKY BRATRSKÉHO

SPOLEČENSTVÍ ZASAZENÉ

NA BRITSKÝCH OSTROVECH

V roce 1936 se rodina Königových vrátila po sedmi letech strávených v léčebně terapeutické rezidenční škole v Pilgrashaimu zpět do Vídně. Hitlerova moc sílila a s ní vzrůstala i protižidovská opatření. König ve Vídni obnovil svou lékařskou praxi a začal se intenzivně věnovat studiu anthroposofie, a zejména myšlence na možnosti jejího praktického využití. V letech 1936-1938 vedl pravidelně se scházející studijní skupinu, která se věnovala zejména teoretickému studiu Steinerových textů a diskutovala nad společným práním přivést $\mathrm{k}$ životu některé ze Steinerových idejí - zejména ty zaměřené na vytvoření bratrského společenství, fungujícího na základě idey sociální trojčlennosti - $\mathrm{v}$ podobě experimentu komunitního života (Müller-Wiedemann, 1996; Bock, 2004).

Již tady byly položeny kořeny koncepce camphillu, bylo by proto mylné tvrdit, že pouze Karl König byl tvůrcem camphillu. Jeho postavení mezi zakladateli je bezesporu významné - byl nositelem ideje, zřejmě i hlavním tvůrcem koncepce, měl letité zkušenosti s léčebně pedagogickou prací díky měsícům stráveným $\mathrm{v}$ institutu Dr. Wegmanové a letům stráveným v Pilgramshainu. Ale ostatních deset zakladatelů mělo při vzniku a následném stabilizování camphillu rovněž důležité postavení a jejich prínos by neměl být opomenut.
Motivační tendence skupiny lidí, kteří založili camphill, lze spatřovat na několika úrovních. Jednou z nich je bezpochyby již zmíněný židovský původ (Karl König, Barbara Lipskerová, Alix a Peter Rothovi, Alex Baum), který přinutil většinu z nich po německé anexi v roce $1938 \mathrm{k}$ odchodu z Rakouska. Židovský původ a tradice tohoto vyznání pro velkou část skupiny znamenaly zejména despotické jednání ze strany rodiny či komunity, což vedlo $\mathrm{k}$ touze po útěku $\mathrm{z}$ těchto okovů a novém životě $\mathrm{v}$ bratrském společenství, $\mathrm{v}$ němž vyznání, stejně jako další individuální charakteristiky člověka, nebudou hrát žádnou roli $\mathrm{v}$ bezpodmínečném přijetí (Müller-Wiedemann, 1996; Bock, 2004).

Paradoxně to nakonec byla právě židovská víra (kterou mnoho $\mathrm{z}$ nich již dávno vnitřně opustilo), co je po vyostření politické situace v roce 1938 přinutilo hrozbou smrti $\mathrm{v}$ koncentračním táboře opustit Rakousko a hledat nový domov mimo území střední Evropy.

Některé ze zakladatelů vedla na cestě $\mathrm{k}$ založení camphillu vlastní zkušenost $s$ léčebnou pedagogikou (Karl König, Tilla Königová a Trude Amannová) a rozhodli se již před odchodem z Rakouska zasvětit svůj život péči a vzdělávání dětí s postižením. Jiné (Barbara Lipskerová) $\mathrm{k}$ tomuto rozhodnutí vedla vlastní zkušenost $s$ mentálně postiženým sourozencem, kterému léčebná pedagogika pomohla získat důstojnější život, než jaký běžně společnost první poloviny 20. století těmto dětem poskytovala. Další se dostali rozmanitými cestami do blízkosti Karla Königa a podlehli jeho charismatu, 
což vedlo $\mathrm{k}$ mnohdy doživotní spolupráci. Např́iklad Anke Weihsová byla tanečnicí, která jako jedna z mála nepocházela z Vídně, ale ani z Evropy. Königa poznala z pozice pacientky a díky jeho lékařským a lidským kvalitám ho následovala nejen na cestě za založením camphillu, ale i na cestě anthroposofie.

Když v březnu roku 1938 Německo zabralo Rakousko a nad Židy se stejně jako nad postiženými lidmi nebo anthroposofy začala stahovat temná mračna, odešli všichni ze studijního kroužku do různých zemí Evropy, v nichž provizorně setrvali nějaký čas, než se o rok později sešli v severovýchodní části Skotska, aby ve farním domku zvaném Kirkton House začali společné myšlenky, zaseté ve vídeňském studijním kroužku, konečně realizovat.

Skotsko jako cílová destinace nebylo náhodnou volbou. Jeho výběr souvisel s pomocnou rukou dr. Wegmanové, která ve švýcarském Institutu léčebné pedagogiky léčila jistou Emily Haughtonovou z Aberdeenshire. Profesionální vztah lékařky a pacientky přerostl záhy $\mathrm{v}$ celoživotní v přátelství. Theodore a Emily Haughtonovi byli součástí velmi dobře rozvinuté anthroposofické sítě ve Skotsku, jejíž mnozí členové byli zároveň vlastníky půdy v Aberdeenshire a významně se podíleli na rozvoji biodynamického zemědělství ve Skotsku. Faktem tedy je, že ač byl život ve farním domku na severovýchodě Skotska nehostinný a pro členy střední vídeňské tř̌́dy obtížný, nebyl životem v naprosté izolaci na místě, kde o Steinerovi a jeho filosofii nikdo nic nevěděl (Jackson, 2015).

\section{Hnutí Camphill jako \\ PRŮNIK ANTHROPOSOFICKÝCH \\ IDEJÍ A PRAKTICKÝCH POTŘEB \\ ZAKLADATELŮ}

Z Kirkton House se zakladatelé, respektive ženská část skupiny a několik dětí (muži byli tou dobou uvězněni na Isle of Man jako nepřátelé státu), přestěhovali do Camphill Estate koncem května roku 1940. Kirkton House kapacitně nemohl stačit potřebám komunity, a tak jim Will MacMillan - vlastník usedlosti Camphill Estate nedaleko Aberdeenu - o šest měsíců později poskytl $\mathrm{k}$ užívání hned několik domů. MacMillan byl sám otcem handicapovaného dítěte, které se právě z nedostačujících kapacitních důvodů Kirkton House nemohlo stát členem komunity (Müller-Wiedemann, 1996; Bock, 2004).

Oficiálně byla činnost Camphillu slavnostně zahájena 1 . června 1940. Jako vůbec první soukromá instituce ve Skotsku poskytující péči mentálně postiženým dětem se Camphill stal velmi rychle vyhledávaným místem nejen ze strany rodičů postižených dětí, ale i lékařů těchto dětí a místních úřadů, které děti $\mathrm{k}$ přesunu do komunity doporučovaly (Jackson, 2013, s. 52).

Camphill se hned od počátku své existence výrazně lišil od jiných rezidenčních škol a domovů svým cílem, kterým nebylo pouze poskytovat dětem $s$ postižením potřebnou péči, ale také jim pomoci rozvíjet potenciál, který je přirozeně skryt v každém dítěti - nehledě na stupeň jeho př́ipadného postižení (König, 1965, s. 145). 
Nutno podotknout, že první camphill vznikl z praktických potřeb uprchlíků, kteři se snažili se svými postiženými i zdravými dětmi začít nový, plnohodnotný život. König a jeho blízcí tedy nepřijeli do Skotska $s$ hotovou koncepcí komunity. Ta se ke své finální podobě vyvíjela a stabilizovala během života v Kirkton House i několika prvních let v Camphill Estate. Každý ze zakladatelů camphillu se věnoval rozvoji a stabilizaci určité oblasti komunity.

Později (v letech 1948-1949) vznikla jako nedílná součást prvního camphillu škola uplatňující waldorfské kurikulum, kterou navštěvovaly zdravé děti pracovníků Camphillu a později i děti s postižením, a to ve třídách smíšených na základě věku dětí, ne zdravotního stavu (Weihs, 1961).

Camphill nebyl, ač by se to mohlo zdát, na britských ostrovech první školou stojící na anthroposofických základech. První rezidenční speciální škola byla založena za pomoci Michaela Wilsona a Friedricha Geutera ve třcátých letech 20 . století v Anglii a předběhla tak první školu v camphillu o více než dekádu (Jackson, 2015).

Počet dětí, ale i pracovníků, kteří přicházeli žít do camphillu, nadále strmě narůstal, a tak záhy ani několik domů v Camphill Estate kapacitně nestačilo. Proto bylo během prvních čtyř let existence komunity postupně pronajato několik dalších usedlostí v sousedství, v nichž našly domov dobrovolníci i děti - rozděleny do domů podle věku, pohlaví a druhu postižení. ${ }^{9}$ Zpočátku patřilly mezi nejčastější diagnózy Downův syndrom a mozková obrna (König, 1947).

Jak zmiňuje König (1947) ve výroční zprávě shrnující kalendářní rok 1946, v prvních letech fungování byly do camphillu posílány děti zejména svými rodiči či opatrovníky (71\%), tj. soukromými osobami, a výrazně méně místními úřady a zdravotnickými organizacemi (29\%). Oproti tomu v roce 1962, jak uvádí Weihs (1972), bylo místními úráady do camphillu posíláno celých $84 \%$ a o deset let později dokonce $92 \%$ ze všech handicapovaných dětí.

Konec druhé světové války znamenal otevření camphillu lidem $\mathrm{z}$ celého světa. Přicházeli do camphillů strávit část života a mnohdy z hnutí už neodešli. Vzhledem ke zvyšujícímu se počtu komunitních domů kolem Aberdeenu, neustálému nárůstu pracovníků a objevujícím se požadavkům na kvalifikovanost a odbornost pečovatelů, pramenícím rovněž $\mathrm{z}$ vývoje speciální pedagogiky, bylo nezbytné začít organizovat systematické vzdělávání členů komunity. První seminární kurz byl otevřen $\mathrm{v}$ roce 1949 , trval dva roky a prošly jím stovky zájemců (Bock in Bang, 2010, s. 49).

Od roku 1951 se Königova idea komunity camphill začala širíit nejen mimo hranice britských ostrovů, ale expandovala na další kontinenty. Př́ćinou vzniku nových společenství však nikdy nebyla iniciativa Königa a jeho spolupracovníků, nýbrž iniciativa pocházející od lidí z konkrétních

\footnotetext{
${ }^{9}$ Praxí se zjistilo, že dětem lépe prospívá, když jsou v rodinných jednotkách více podobných reálné rodině, tzn. že skupiny jsou rozmanité věkem, pohlavím i druhem postižení. Způsob vytváření skupin v jednotlivých domech se $\mathrm{v}$ důsledku této skutečnosti změnil a přetrvává v komunitách dodnes.
} 
míst (mnohdy rodičů postiženého dítěte), kteří Königa žádali o pomoc se založením camphillu v dané oblasti.

Dnes hnutí Camphill zahrnuje více než 115 komunit ve více než 20 zemích celého světa. Přestože jeho centrem zůstala i nadále Evropa a zejména britské ostrovy, našel si camphill cestu i na americký kontinent, do Asie i Afriky.

\section{LÉČEBNÁ PEDAGOGIKA A IDEA SOCIÁLNÍ TROJČLENNOSTI JAKO HLAVNÍ PILÍŘE TERAPEUTICKÉ PRÁCE V CAMPHILLU}

Camphill je společenství, $v$ němž se snoubí dva paralelní impulsy - již zmíněná potřeba vytvoření alternativní společnosti fungující na bázi Steinerovy sociální trojčlennosti, jejiž původ lze u skupiny zakladatelů hledat $\mathrm{v}$ individuálních i společných motivech, a léčebně pedagogický impuls, vycházející z nepřívětivého společenského postavení mentálně postižených dětí ve stř̌ední Evropě ve 20. letech minulého století.

\subsection{Léčebná pedagogika jako náplň terapeutické práce v camphillu}

Léčebná pedagogika je oborem, o jehož celosvětové rozšíření se zasloužili zejména zakladatelé camphillu a jehož koncepce péče o mentálně postižené jedince vychází právě z léčebně pedagogických principů. Duchovní počátky léčebné pedagogiky spatřoval Karl König (1960a; 1960b) zejména v práci a odkazu lékařů Itarda, Séguina a Guggenbühla. Společným jmenovatelem průkopníků léčebné pedagogiky bylo úsilí o rozpoznání potřeb postižených dětí a nalezení způsobu, jak jim život v handicapu pokud možno usnadnit. Způsobem, jakým tito lékaři pracovali, se dle Königa nevědomky stávali prvními léčebnými pedagogy. ${ }^{10}$

Teorie i praxe léčebné pedagogiky vzešla ze spolupráce Steinera a Wegmanové ${ }^{11}$, která přivedla ve 20. letech v Arlesheimu $\mathrm{k}$ životu a praxi Steinerovu ideu tzv. Heilpädagogik ${ }^{12} \mathrm{v}$ podobě prvního léčebně pedagogického domova pro postižené děti.

Definici léčebné pedagogiky přinesl August Homburger (autor první obsáhlé př́ručky o léčebné pedagogice), který ji vymezil jako „kombinaci edukace a vyučování s intervencí, jejichž cílem je léčit, zlepšit a vyvážit nedostatky duševního zdravi" (König, 2009, s. 40). Z této definice vychází v camphillu realizace léčebné pedagogiky, která spočívá ve snaze pomoci těm jedincům, kteří jsou oslabeni fyzicky nebo psychicky, posílit nejen vhodným terapeutickým prrístupem, ale komplexně celým prostředím, které je obklopuje, oslabené části jejich těla či duše.

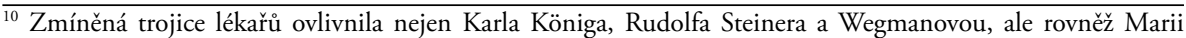
Montessori, která zejména z výzkumů obou francouzských lékařů vycházela př̀i vytváření svých metod práce se zanedbanými a mentálně postiženými dětmi.

${ }^{11}$ ItaWegmanová (1876-1943) byla švýcarská lékařka, blízká spolupracovnice Rudolfa Steinera, zakladatelka a ředitelka léčebně pedagogického institutu v Arlesheimu

${ }^{12} \mathrm{~V}$ angličtině označována pojmem curative education, $\mathrm{v}$ češtině pojmem léčebná pedagogika.
} 
Na konci 50. let König o léčebné pedagogice napsal, že byla a je stále se rozvíjející vědou, která má spojitost např́klad $s$ dětskou psychiatrií, pediatrií, neurologií a psychologií. Zároveň by měla být praktickým uměním, které hraje svou roli nejen v pedagogice, ale i v terapii řeči, fyzioterapii, eurytmii a léčebné eurytmii, malování i kreslení, hudbě a muzikoterapii, rukodělných činnostech (tkaní, keramika, práce se dřevem) či ergoterapii. $V$ nejširším slova smyslu by pak léčebná pedagogika měla být lidským postojem (Hansmann, 1992, s. 23).

Léčebná pedagogika je ve své podstatě komplexním terapeutickým přístupem $\mathrm{k}$ dítěti s postižením, jehož základem je otevřený a nikdy nekončící tvưrčí proces hledání vztahu mezi vychovatelem a dítětem. Jak ř́ká Hansmann (1992, s. 35), každé dítě - nehledě na př́ípadné postižení či snížené intelektové schopnosti - přichází na svět $s$ právem na celkové vzdělávací prostředí. Součástí jejího holistického př́stupu, jak uvádí např́iklad Hartová a Monteuxová (2004, s. 69-70), jsou výchova a vzdělání $\mathrm{v}$ nejširším smyslu - důraz je kladen na praktické, sociální a umělecké dovednosti; řemesla, rukodělné činnosti a smysluplnou práci; terapeutický př́stup je vytvořen na míru každému dítěti či dospělému s mentálním postižením.

Holistický přístup je tedy $\mathrm{v}$ camphillech uplatněn nejen ve vzdělání v rámci škol, které jsou součástí některých komunit, ale znamená komplexní výchovný a vzdělávací př́stup celého prostředí camphillu, komunitních domů, kde pokračuje důraz na praktické, sociální a umělecké dovednosti. Komunity pro dospělé jedin- ce s mentálním postižením jsou zaměřeny na nepřestávající upevňování základních vědomostí, stimulují zájem $\mathrm{v}$ místních a světových záležitostech a podporují stále pokračující rozvoj individuálních zájmů každého jednotlivce. (tamtéž)

Řemeslná práce a smysluplná práce na zahradě či v domě poskytují prostředky ke stimulaci kognitivních procesů a pomáhají rozvíjet motorické dovednosti. Zároveň pomáhají rozvíjet smysl pro krásu a $\mathrm{v}$ neposlední řadě přinášejí radost $\mathrm{z}$ vytvoření výrobku, který má zpravidla praktické využití a zároveň esteticky prŕíjemný vzhled.

Terapeutický přístup, jehož cílem je harmonizovat vrozené či vývojové nevyrovnanosti (postižení, které se projevují v chování jedince), je vytvořen na míru každému dítěti na základě rozhovoru rodičů, odborných lékařůu, vychovatelů, učitelů a dalších lidí, kteří žijí a pracují s daným jedincem. Tento př́stup se vytváŕí $\mathrm{v}$ rámci spolupráce při tzv. setkání kolegia.

Základním principem každodenního terapeutického prrístupu $\mathrm{v}$ camphillu je (stejně jako ve waldorfských školách) práce s rytmem. Zdravý rytmus ve stř́idání aktivity a odpočinku, společných činností s individuálními aj. podporuje terapeutickou kvalitu života $\mathrm{v}$ komunitě (tamtéž).

Péče jako další z prvků léčebné pedagogiky vychází z života v komunitním domě, v němž převládá bezpečí, ale je zároveň esteticky prŕjemným prostředím. To podporuje a stimuluje sociální a emocionální rozvoj dětí. Jednotlivci jsou podporováni v utváření schopnosti činit své vlastní volby a rozhodnutí v rámci vzájemné 
zodpovědnosti, stejně jako v rozpoznávání potřeb, práv a přání druhých lidí. Každý jedinec (at' už zdravý, nebo s postižením) je schopen dělat smysluplnou práci na základě svých individuálních schopností a možností, což vede $\mathrm{k}$ vytváření pocitu sounáležitosti ve společenství (tamtéž).

\subsection{Idea sociální trojčlennosti v camphillu}

Steinerova idea sociální trojčlennosti volně vychází z hesla francouzské revoluce svoboda, rovnost, bratrstvi a je takovým modelem sociálního uspořádání, kde v oblasti kulturně-duchovní je uplatňován princip svobody, $\mathrm{v}$ politicko-právní princip rovnosti a $\mathrm{v}$ hospodářské sfére princip bratrství (Hradil, 2002, s. 215).

Podněty blízké sociální trojčlennosti, na něž navázal svou prací Steiner, můžeme nalézt i u tří významných osobností, které inspirovaly Königa při vytváření filozofické koncepce camphillu - J. A. Komenského (1592-1670), knížete Mikuláše Ludvíka Zinzenforfa (1700-1760) a Roberta Owena (1771-1858). Tyto tři muže spojovalo úsilí vytvořit nový společenský rád, fungující na principech bratrství (König, 1960c; Müller-Wiedemann, 1996).

König v meditacích pro camphill uve$\mathrm{dl}$, že členové komunity sdílejí práci v bratrství, jsou si rovni před tváŕí boha a jsou svobodni jako jednotlivci při individuálním osvojování anthroposofie. Prostřednictvím těchto principů se všichni lidé snaží stát pravdivými lidskými bytostmi ve službě lidskosti (König in Bang, 2010, s. 70).
Samotná realizace sociální trojčlennosti souvisí v camphillu se třemi piliŕri komunity, jimiž jsou tzv. setkání kolegia, biblický večer a Steinerův základní sociální zákon.

Takzvané setkání kolegia, které je inspirováno pansofickými ideami Komenského, je pravidelným setkáváním všech pečujících, jehož cílem je co nejlépe porozumět potřebám každého dítěte/dospělého, o něhož je pečováno v camphillu. Projednávají se na něm důležitá komunitní témata a je rovněž oblastí, která poskytuje prostor pro společné vzdělávání, kulturní život a výzkumnou činnost. Setkávání kolegia nemá svůj původ v camphillu, nýbrž ve Steinerových waldorfských školách, kde je jeho náplň a struktura obdobná jako v camphillu. Je aspektem kulturně-duchovní sféry, v níž se uplatňuje princip svobody (Luxford in Bang, 2010, s. 66).

Princip rovnosti se v camphillu objevuje prostřednictvím tzv. biblického večera. Ten je originální myšlenkou Königa, která vyvstala ze snu, v němž figuroval jako Königův učitel již zmíněný Zinzendorf. Na základě Zinzendorfova „snového“ doporučení založil König v camphillu tradici pravidelného sobotního setkávání, jehož smyslem je individuální duchovní prríprava na nadcházející týden př̀i společném jednoduchém, avšak slavnostním stolování, četbě z předem stanovené pasáže z Bible a vzájemném sdílení dojmů z četby (König, 1960c, s. 18).

Sdílení práce v duchu bratrství, které je třetím z principů sociální trojčlennosti, je $\mathrm{v}$ camphillech naplňováno prostřednictvím již zmíněného základního sociálního zákona, který Steiner vytvořil jako návrh nového ekonomického řádu ve společnosti. $V$ camp- 
hillu je každý komunitní dům samostatnou ekonomickou jednotkou, zodpovědnou za vlastní finance. Pracovníci a dobrovolníci camphillu, kteří bývají souhrnně nazývání co-workeři, v původním Königově plánu nejsou ohodnocováni za svou práci pravidelnou mzdou, ale komunita hradí jejich výdaje (König, 1960c, s. 42-43).

$\mathrm{V}$ dnešní době je ale situace $\mathrm{v}$ camphillech velmi odlišná od pionýrského období, v němž camphilly nepodléhaly žádným státním regulacím. Nové generace co-workerů $\mathrm{v}$ komunitách mnohdy nesdílejí původní ideály zakladatelů. Cesta individualismu, na kterou jsme se jako společnost s prudkým rozvojem informačních technologií a zejména sociálních sítí vydali, omezila setkávání tváří v tvář, což se projevuje i v camphillech. Komunit, které dodržují biblický večer stejně jako setkání kolegia, ubývá. Vzhledem k měnícím se legislativním opatřením $\mathrm{v}$ mnoha zemích rovněž dochází k úbytku camphillů, $\mathrm{v}$ nichž co-workeři dodnes pracují bez zaměstnanecké smlouvy. Zůstává otázkou, jak se Königovy původní principy a z nich vycházející piliŕre camphillu budou $v$ jednotlivých camphillech vyvíjet dál a jestli $v$ budoucnu nezůstanou jen odleskem pionýrského období, které nepřetržitý vývoj společnosti - stejně jako přirozený vývoj komunity - definitivně překonal.

\section{ZÁVĚR}

Hnutí Camphill má ve světě tradici dlouhou více než 75 let a stejně dlouhou dobu fungují jednotlivé camphilly po celém světě jako právoplatné alternativy institucí pro mentálně postižené děti, dospívající a dospělé. Přesto je povědomí o jejich existenci v české laické i odborné veřejnosti velmi nízké.

Př́spěvek poskytl úvod do problematiky hnutí Camphill, a to z pohledu celkového kontextu období vzniku hnutí - sociálněpedagogické reformy společnosti první poloviny 20 . století, reformního pedagogického hnutí a ideového rámce camphillu, kterým je anthroposofie. Na postavách zakladatelů hnutí - Karlu Königovi a jeho spolupracovníků - nastínil specifika celospolečenského reformního hnutí, stojícího na hledání alternativních cest proti dopadům liberalismu společnosti počátku 21. století, a zároveň poukázal na společné prvky v motivaci zakladatelů $\mathrm{k}$ vytvoření bratrského společenství, pracujícího na duchovním pozadí anthroposofie a využívajícího principù léčebné pedagogiky v praktickém každodenním životě a práci v komunitě.

Studie poukázala mimo jiné také na dosud málo prozkoumanou názorovou a ideovou pestrost pohledů na působení v oblasti kulturně společenských reforem $\mathrm{v}$ průběhu 20. století, které postupně zabarvují dosavadní dvoupólové nebo černobílé pohledy na sledovanou problematiku. To se týká nejen zahraničí, ale i vývoje pedagogického myšlení v Československu.

Karl König, stejně jako historie i současnost hnutí Camphill (včetně vývoje léčebně pedagogických myšlenek v Čechách a více než desetiletá existence Camphillu na soutoku v Českých Kopistech) je tématem rozpracované disertační práce autorky článku. 


\section{Literatura}

Bock, F. (Ed.). (2004). The builders of Camphill: lives and destinies of the founders. Edinburgh: Floris Books.

Bang, M. J. (Ed.). (2010). A portrait of Camphill: from founding seed to worldwide movement. Edinburgh: Floris Books.

Fajkus, B. (2005). Filosofie a metodologie vědy. Praha: Academia.

Hansmann, H. (1992). Education for special needs: principles and practice in Camphill Schools. Edinburgh: Floris Books.

Hart, N., \& Monteux, A. (2004). An introduction to Camphill communities and the BA in curative education. Scottish Journal of Residental Child Care, 3(1), 67-74.

Hradil, R. (2002). Průvodce českou anthroposofii. Hranice: Fabula.

Jackson, R. (2013). Karl Koenig, Stanley Segal, and Herbert Gunzburg: pioneers in the field of intellectual disability in Britain. International Journal of Developmental Disabilities, 59(1), 47-60.

Jackson, R. (2014). Dr. Karl König: a brief surfy of his extraordinary early years. Scottish Medical Journal, $0(0), 1-4$.

Jackson, R. (2015). Anthroposophical hotspot. Camphill Correspondence.

Kasper, T., \& Kasperová, D. (2013). Dějiny pedagogiky. Praha: Grada.

Koenig, B. (2010). Recollections of my life. [Transl. by Robin Jackson]. Drumoak: Robin Jackson.

König, K. (1947). The Camphill Rudolf Steiner Schools for children in need of special care. Superintendent's Report. January 1946 to January 1947. Aberdeen.

König, K. (1960a). Mignon. A tentative history of Curative Education I. The path of curative education. The Cresset, 6(4).

König, K. (1960b). Mignon. A tentative history of Curative Education II. The path of curative education. The Cresset, $7(1)$.

König, K. (1960c). The Camphill Movement: two essays. Botton Village: Camphill Press on behalf of the Association of Camphill Communities.

König, K. (1965). The three essentials of camphill. The Cresset, 12(1).

König, K. (2009). The child with special needs: letters and essays on curative education. Edinburgh: Floris Books.

Matulčíková, M. (2007). Reformno/pedagogické a alternativne školy a ich prinos pre reformu školy. Bratislava: Musica Liturgica.

Müller-Wiedemann, H. (1996). KarlKönig: a Central-European biografy of the twentieth century. [Transl. by Simon Blaxland-de Lange, edited by Friedwart Bock]. Whitby: Camphill.

Průcha, Jan. (2012). Alternativní školy a inovace ve vzdělávání. Praha: Portál.

Reformni hnuti v ČSR ve 30. letech. Sborník prríspěvků ze semináře pořádaného katedrou pedagogiky PedF UK, 6. února 1996.

Rýdl, K. (1994). Alternativni pedagogické hnutí v současné společnosti. Brno: Marek Zeman. 
Selg, P. (2008). Ita Wegman and Karl König: letters and documents. Edinburgh: Floris.

Stearns, P. N. (2001). Encyclopedia of European social history from 1350 to 2000. New York: Scribner.

Steiner, R. (2000). O poznáváni vyššich svètů. Michael.

Václavík, V. (1997). Cesta ke svobodné škole. Kapitoly ze srovnávaci pedagogiky. Hradec Králové: Líp.

Valenta, M., \& Krejčíŕová, O. (1997). Psychopedie: kapitoly z didaktiky mentálně retardovaných. Olomouc: Netopejr.

Valenta, M. (1995). Camphillské hnuti a německý výchovně vzdèlávaci systém: (péče o mentálně postižené v zahraniči II) : pro posluchače speciální pedagogiky. Olomouc: Vydavatelství Univerzity Palackého.

Valenta, M. (1993b). Waldorfská pedagogika a jiné alternativy. Olomouc: Vydavatelství Univerzity Palackého.

Valenta, M. (1993a). Péče o mentálně postižené v zahraniči (Holandsko a camphillské hnutí): pro posluchače učitelstvi ŠMVZP. Olomouc: Vydavatelství Univerzity Palackého.

Weihs, A. (1961). Camphill's first twenty-one years. The Cresset, 7(4).

Weihs, T. (1972). The Camphill Rudolf Steiner schools for children in need of special care. Report, 1962-1972. Aberdeen.

Mgr. Šárka Klímová,

Katedra primárni a preprimárni pedagogiky, Pedagogická fakulta Univerzity Palackého, Olomouc;

e-mail: klimova.sar@gmail.com

KLÍMOVÁ, Šárka: The Camphill Movement against the Background of Social Educational Reform at the Beginning of the Last Century

This study in educational history aims to present the Camphill movement, its history and the range of current problem areas relating to the functioning of comunities, particularly the British ones, that have now existed for more than 75 years. The main theme is the camphill anthroposophical community, which was the point of intersection of two independent aspirations - the provision of education for children with mental disability at a time when these children were considered to be ineducable, and the creation of an alternative community in which human equality would not depend on inner or outer criteria. The first part of the study is concerned with the reasons for the combination of these aspirations in the conception of the camphill community together with a brief account of the development of camphill in the Camphill international movement, including the role of the Czech Republic within it. The second part offers an outline of the current challenges facing the movement as a consequence of that development.

Keywords: camphill, Camphill Movement, Karl König, therapeutic education, Ita Wegman, anthroposophy, Rudolf Steiner, community. 